\title{
The Impact of Childhood Abuse on University Women's Career Choice ${ }^{1}$
}

\author{
Rosemary C. Reilly \\ Assistant Professor \\ Concordia University \\ Montréal, Québec \\ Miranda D'Amico \\ Associate Professor \\ Concordia University \\ Montréal, Québec
}

A study is discussed that describes a link between childhood abuse and career choice for 12 university women. Purposive sampling was used, and the study employed a cross-case comparative approach with an emphasis on feminist principles. An interactive, collaborative interview was developed, prompting stories that reflected career choice processes. A general framework for processing the naturalistically obtained data was constant across the cases and was subjected to criteria to insure trustworthiness. Three basic themes emerged: (1) for women who were still enduring a cycle of pain and fear as a result of long-term child abuse, safety was a dominant concern; (2) women who had managed to transform their experiences approached career choice as a "mission" in order to right the wrongs of their past; and (3) negative cases that did not fit the general trend provided an opportunity to reexamine the data and the theme of distance. These results have important implications for vocational counseling and academic advising.

1. This research was supported through a grant from the General Research Fund from the Social Science and Humanities Research Council, Concordia University. 


\section{INTRODUCTION}

Violence has long been a specter that haunts the human experience. The psychological impact of violence on individuals and family relationships is well known; however, the long-term impact on life choices is not. Researchers (Browne \& Finkelhor, 1986; Finkelhor \& Browne, 1985; Newberger \& DeVos, 1988) have implied that the impact on the future of an abuse survivor would be feelings of powerlessness to act on wishes and beliefs, self-destructive behavior, loneliness, poor self-esteem, and revictimization. These patterns might extend themselves into the career choice context.

This study arose out of our observations from a pilot qualitative study on the effects of violence on the learning of university women (Reilly \& D'Amico, 2002). A majority of the participants disclosed to us that their child abuse experiences influenced their choice of a university major leading to a professional career. The purpose of this study, conducted as a followup to the previous research, uses a feminist research design to describe the impact abusive experiences may have had on career choice, in order to further clarify the societal cost of family violence.

\section{RELEVANT LITERATURE}

Recent investigations have shown that adult abuse significantly impacts women's ability to find work and maintain employment (Moe \& Bell, 2004); women's job performance as measured by absenteeism, tardiness, job leavings, and terminations (Swanberg \& Logan, 2005); and their ability to concentrate on the job (Wettersten et al., 2004). Chronister and McWhirter (2004) found that battering could create barriers to pursuing educational goals. However, violence can extend its influence before gainful employment is attained, and it can be rooted in childhood abuse experiences. In one pilot study (Reilly \& D'Amico, 2002), participants mentioned that their past abusive experiences influenced their choice of career, either in choosing a helping profession, or in seeking departments that were populated mainly by women. However, little research has been done in this area (Dickinson, 1991).

Most research in the vocational domain has been an effort to rebalance women's presence in traditional and nontraditional careers. Therefore, much has focused on the variables that influence women in choosing a career. The concepts of self-efficacy (Betz \& Hackett, 1986; Hackett \& 
Betz, 1981; Rotberg, Brown, \& Ware, 1987), attribution (Fiorentine, 1988; Luzzo, Funk, \& Strang, 1996), self-concept (Betz \& Fitzgerald, 1987; Love, 1986), psychological influences (Roundtree \& Frusher, 1991), social and cultural factors (Hackett \& Byars, 1996; Reis, 1995), sexual orientation (Fassinger, 1996), and family patterns (Goldwasser, 1992; Whiston, 1996) have all been the subject of investigation.

The literature on sexual harassment of high school girls demonstrates that a long-term effect of harassment is to limit the educational and vocational opportunities for young women. Levels of sexual harassment determined girls' selection, attendance, and success in courses that were mainly populated with boys (Larkin, 1994; Yewchuk, 1994). Sexual harassment also influences women's ability to stay and succeed in nontraditional jobs or in male-dominated fields (Benson \& Thomson, 1982). Sexual harassment has been described as the single most widespread occupational hazard women face in redressing the gender imbalance in many fields (Betz \& Fitzgerald, 1987; Mansfield, Koch, Henderson, Vicary, Cohan, \& Young, 1991; Swerdlow, 1989; Tangri, Burt, \& Johnson, 1982; Working Women's Institute, 1980). Personal histories of childhood abuse may play a similar role in limiting women's career choice.

Abuse has been seen to have far-reaching effects in the realm of epistemological processes and self-concept, salient dimensions in career development. Belenky, Clinchy, Goldberger, and Tarule (1986) found that $38 \%$ of the women in school or college, and $65 \%$ of the women contacted through social service agencies, experienced incest, rape, or sexual seduction. Many survivors perceived themselves to be mindless and voiceless, subject to the whims of authority. They did not cultivate representational thought and believed knowledge to be a magical process beyond their grasp. Sexual violence, in particular, functioned as an effective technique of silencing. Violation and shame undermined the process of gaining and valuing subjective knowledge (Belenky et al., 1986), and many women began to conceive of themselves as "invisible." This dynamic may exert a similar effect on a woman's ability to make career choices and to function within certain professions.

\section{PURPOSE OF STUDY}

This study explored the significance of the relationship between childhood abuse and career choice in university women. The researchers developed an inquiry process that attempted to detail the impact of these events on career choice. 


\section{THEORETICAL FRAMEWORKS THAT GUIDE THIS INQUIRY}

Though there is a major debate about whether we as researchers can, and indeed should, identify a distinct feminist methodology (Ramazanoglu \& Holland, 2002), we have conducted this inquiry guided by feminist epistemological and methodological frameworks. A basic assumption of our approach is that family violence is a patriarchal process, whose casualties are women, men, and children. We view gender as an organizing principle in this research, and we seek to understand how a gendered social order has shaped women's lives, their consciousness, and career choice. Our aim is to render visible the distortion that abuse has on the female experience in order to illuminate and end women's unequal social position. We do this by integrating women's knowledge and experiences with a multiplicity of women's own voices. Our approach to research is informed by the following principles (Fonow \& Cook, 1991; Meis, 1991; Reinharz, 1992; Stanley \& Wise, 1993):

- The research relationship should not be a hierarchical relationship but a collaborative one.

- Emotions of the researcher and the participant are valuable aspects of the research process.

- Objectivity is not an ideal stance; researcher subjectivity is a powerful asset.

- The researcher's intellectual autobiography informs the framing of the conclusions.

- The researcher must effectively blend the different "realities" held by the researcher and the participant.

- The researcher must be aware of issues surrounding authority and power.

Methodologically, we employed techniques and processes that established collaborative and nonexploitative relationships with participants, emphasizing trust, reciprocity, and empathy. We avoided objectification of the participants and their experiences by adopting shifting situational identities (Angrasino \& Mays de Perez, 2000) that were harmonious with the social interaction and context (as women, teachers, learners, mothers, and as a survivor). We negotiated the meanings of the results with the participants and were self-reflexive about what we ourselves were experiencing and learning. And we are disseminating these results in order to produce research that is educationally and vocationally transformative. 
In terms of the actual career choice processes that were under investigation, a grounded theory approach was used (Strauss \& Corbin, 1998). We developed a rough definition of the career choice phenomena to be explored. Dimensions of this definition were: present course of study, long-term plans for employment, and the self-construction of a "dream career" from the participant's perspective.

We then formulated a tentative hypothesis to explain the phenomenon on the basis of the cases reported in the study and our own insight into the data. Based on the data generated from the first case study, we conducted a comparison with the case participant regarding the fit between the hypothesis and the data. We reformulated the hypothesis and redefined the phenomenon in response to the comparison with each succeeding comparison case. We then delimited the hypothesis by comparing it with the negative cases, reformulating or redefining as necessary with the case participants.

\section{METHODOLOGY}

\section{Research Design}

This study employed a cross-case comparative study approach (Merriam, 1998). We selected this methodology on the basis of (1) its flexibility and adaptability to the description of multiple realities, (2) its potential transferability to other participants and age groups in order to build a foundation of description, (3) its susceptibility to a self-reflexive and empowerment process, and (4) its congruent positioning with our ethics and values as researchers in regard to social change and the research process (Lincoln \& Guba, 1985).

Interviews were a cooperative and interactive process, minimizing hierarchical relationships in favor of a joint enterprise approach (Oakley, 1981). Using an open-ended conversational format to facilitate the development of trust, rapport, and maximum exploration of the phenomenon, we, as interviewers and collaborators, attempted to elicit stories from the participants, since stories reflect human consciousness (Vygotsky, 1987). Interview questions were designed to prompt reconstructions of the reasons for their choice of courses and majors, past experiences with childhood abuse (being aware of psychological boundaries and privacy issues), and the here-and-now self-constructions of 
the participants as career choosers and emerging professionals. Questions also attempted to elicit feelings, thoughts, intentions, and meanings. Some examples of the questions posed are:

1. What is your major?

2. What career do you aspire to enter?

3. What are some of your motives for this career choice?

4. What past experiences led you to this choice?

5. Tell me about how you see yourself in this career in the future.

6. For how long have you aspired to this career?

7. Do you see any links between your childhood experiences and your career path? What specifically? If not, describe why not.

\section{Participants}

The focal points of the cross-case comparative study were 12 women participants who experienced physical, sexual, or emotional (including verbal and psychological) childhood abuse (as defined by the Intergovernmental Committee on Family Violence, 1991). The women belonged to various age, racial, class, and ethnic groups; and they were enrolled in a university undergraduate program.

\section{SAMPLING}

Since this project was concerned with university women who have had previous child abuse experiences, we used purposive sampling. Lincoln and Guba (1985) suggested this method in order to increase the scope or range of data exposed, since random sampling may not produce the kind of sample that the project concerns. We recruited volunteers from the campuses of two large universities in a major Canadian city through advertisements and flyers distributed in classes. We established various methods for contact (voice mail, e-mail, and a letter box) that allowed prospective volunteers various degrees of anonymity before consenting to participate. Prospective participants could then self-select out of the study. Though this might have biased the sample, we believe that, ethically, due to the sensitive nature of the research topic and our feminist stances, participants should exert maximum control and freedom over their own participation. 


\section{Phases of InQuiry}

We conducted all interviews in person, and each interview was audiotaped, while maintaining ethical considerations of confidentiality and emotional distress. We used the format of the three-interview series (Seidman, 2006).

1. Orientation and overview. The first interview addressed issues of informed consent: an explanation of the motives and intentions in the research process, the purpose of the inquiry, the protection of the participants, the discussion of the collaborative nature of the analysis, logistics, and the consent form (Bogdan \& Biklen, 1998). The interview then proceeded to a focused life history, in which the participant's reasons for course and career choice were placed in context. This session accentuated reconstructions of reasons for course concentration selection and past experiences with violence (with appropriate privacy and psychological boundaries being maintained).

2. Focused exploration. The purpose of the second interview was to concentrate on the concrete details of the participants' present experiences, including their here-and-now self-constructions as career choosers and emerging professionals. This interview took place approximately 2 weeks after the first one.

3. Member check phase. In this interview, participants reflected on the meaning of their experiences, in light of the data generated. They were asked to comment on its accuracy, analyze its meaning and implications, and clarify any ambiguities or inconsistencies. This phase took place approximately 3 to 4 weeks after the second interview.

\section{Analysis Procedures}

We created a general framework for processing the data, and we used it consistently and continuously across the cases (Strauss \& Corbin, 1998). Our research design and analysis was an interactive, reiterative one (Maxwell, 1996), whereby we analyzed the data in a current case while continuing to collect data from additional cases. We performed a provisional categorizing of the data (units that seemed related to the same content) and formed propositional statements to characterize a category. Each case participant reviewed the categorizations and propositional statements; and she was able to clarify, revise, and add elements (Miles \& Huberman, 1994). 
We developed rules for categorizing the data (i.e., the inclusion of units with similar meaning into the same category) in order to keep the category internally consistent (Dey, 1999). We checked the coherence of these rules with each participant to maintain the integrity of the representation of her experience. We gave each category a metaphoric title, which attempted to capture the essence of the rule for inclusion of units into the category. We reviewed the data to check for consistency and relevance, and we proceeded with this process until the four criteria proposed by Lincoln and Guba (1985) were fulfilled: exhaustion of data sources, saturation of categories, emergence of regularities, and overextension. We then created clusters of categories and formalized their relationship to other clusters in order to facilitate the development of theory. We subjected the data to various criteria and procedures to ensure trustworthiness (Lincoln \& Guba, 1985; Merriam, 1998), including credibility, transferability, dependability, and confirmability.

\section{RESULTS}

Three basic themes emerged from the interview data. The following are illustrations of the patterns that emerged. We have selected passages from the words of some of the participants that most aptly describe the theme.

\section{"I Want To Be Safe Now": Issues of Physical and Psychological Safety}

For those four women who were still enduring a cycle of pain and fear as a result of devastating long-term effects of chronic child abuse, safety was a dominant theme. Choices concerning course work and fields of study were determined by levels of safety, which was defined by them as the presence of women and the absence of men.

Louise, ${ }^{2}$ a 54-year-old woman, disclosed being sexually assaulted at the age of three by a male relative. This abuse occurred frequently until she was 9 years old, at which time she was able to report these events to her parents. Though her parents stopped the abuse, they never acknowledged the effects it may have had on her, and the abuse was shrouded in silence. In her interview, Louise described that she felt more comfortable and safer in smaller classes that had a majority of women students; in fact, her future career plans were based on the fact that the department in which she was

2. All names are pseudonyms. 
enrolled had a majority of female faculty and students. Louise said, "It was very hard for me to come back to school. I really checked things out so that I'd know I'd be okay." She revealed that she felt safer in that department than elsewhere in the university. Watching others in order to keep herself safe was a major thread to her reconstructions. According to Louise, "With one classmate [a man], I felt very intimidated by him when we had to work together. I would watch him to see if he was judging me ... to size him up."

She disclosed that her biggest challenge in university was to open herself up to "men's viewpoints," particularly in the context of family studies. She stated that often she would find herself being overly anxious when "too many men were in class." She would purposely sit next to groups of women and would only take courses that were offered during the day, because she felt at risk at night. She reported experiencing particular difficulty in the process of forming learning partnerships with men; she often had to seek out the help and support of her therapist in order to construct appropriate boundaries for these situations. She insightfully summed up her understanding of her patterns by stating in a clear though wavering voice, "It's hard when you've experienced something [sexual abuse] and you've learned the wrong way to cope [avoiding men], but you've survived."

For other participants whose career choice fit this theme, safety was also psychological; freedom from manipulation or "hidden agendas" by professors, especially male professors, was seen as very important. These women were extremely sensitive to power hierarchies. Rosalyn, an immigrant woman of color in her mid-30s who experienced extreme physical abuse at home and at school, said, "Female professors generally are very approachable. With male professors, you have to watch out for power dynamics. ..." When asked about what kind of power dynamics, "Power trips," she added formidably, "especially since I'm Black."

Trust issues both inside and outside the classroom were extremely salient within this category. This issue was particularly resonant for Elaine, a 20-year-old woman who was physically, psychologically, and emotionally bullied by peers:

Because of her [a female professor], I have a 'voice' in the classroom. I knew then I'd have a 'voice' in [her chosen field]. In other courses I'd taken in other [male-dominated] departments, there was a lack of authenticity. ... You couldn't trust that what they said was what they really thought and felt. 
These women then used the presence of female faculty to determine their course concentration and subsequent career path.

\section{“I Want To Make Things Right:" Career as Mission}

Another major theme that emerged was from six women who had managed to transform the pain and fear of chronic physical and sexual abuse into a career-as-mission in an effort to right the wrongs of their past. This sense of duty often took them into the realm of social services careers or vocations that involved work with women, children, or families. Choices concerning coursework and fields of study were less influenced by the context than the focus: The transformation of past abusive experiences was facilitated by a new career path and compelled the desire to effect transformative social change.

Isabella, an eastern European immigrant woman in her mid-50s, described her early paternal relationship with undertones of sexual imagery, though she does not have any recollection of incest. Rather, her father tended to react as if male figures around the family would molest her and, therefore, kept her fairly isolated from others. She disclosed being sexually abused at the age of 11 by a male teacher who would regularly fondle her intimately during school assemblies. This sexual abuse lasted until she was 13 , at which time the teacher lost interest in her. When he began to exhibit attention toward her younger sister, Isabella told her father about the abuse. The teacher was driven from the town, but silence prevailed as a coping mechanism for the family. This pattern of acting in defense of others was further demonstrated when Isabella spoke about leaving her physically abusive husband. "I decided that I had to stop the cycle when my daughter became pregnant. I made a gift to the girl child, a promise that she would not endure what my daughter had."

Isabella retreated to a women's shelter and was encouraged there to return to school in an effort to rebuild her self-concept and find satisfaction on a new path. While still living at the shelter, she began working with other women who were experiencing domestic violence and had also endured childhood abuse. She discovered that helping others facilitated her own healing. By connecting with others, she was able to engage in a two-way process in order to overcome the isolation of lifelong abuse. As well, Isabella wanted to effect social change, an exceptionally strong theme with survivors of domestic abuse. 
I want to give a voice to women. For so long, I didn't have a voice. I want to create a safe place for women to come to. Not only physical, but mental, psychological ... and I do this in my healing circles which I have facilitated since I got my certificate. I also want to understand why I became a battered wife. All my papers and assignments help me to understand what happened to me.

Other participants for whom this was a dominant theme related that taking action through a career was a major part of their survival process. Monica, a 24-year-old woman who was a first-generation Canadian, recalled:

I remember when I was 12 years old, after being beaten by my [parent], I vowed I would never let anyone else suffer the way I had. That's when I decided I would be a counselor to work with others . . . to stop this cycle. This [vow] was the only thing that kept me sane.

For others, the impact did not need to be so dramatic. Christina, a mature student in her mid-40s who was in the process of completing a certificate in a helping profession, extended this sense of mission to her current job. "Even as a secretary, it is important to be able to make a difference . . . to make things better. What I learn in my classes allows me to put a human face on my job: to be and to act human, even in a big organization." Transformation through career choice of past painful experiences for the good of others was a crucial process for these women.

\section{“Distance:” The Negative Cases}

Negative cases are cases that do not seem to fit the general trend and, therefore, provide researchers with opportunities to re-examine the data in order to explain why those cases have happened in such an untypical way (Glaser \& Strauss, 1967; Seale, 1999). Re-examination of the data allows for the modification of ideas and assumptions, and eventually a richer and more complex theory and explanation. In the context of this inquiry, a negative case was defined as a participant who did not base her career choice on her past childhood abuse experiences. Two women fit this criterion, and they were women who experienced emotional abuse. These women had a more cognitive than affective basis for their career choice. These women were attracted and connected to the content of the field. They spoke of past influences on their present choice, but these influences 
were always described with images that evoked distance and kept issues, their past, and people at "arm's length." Their main concern was to increase awareness, while leaving change up to other individuals or organizations.

Anya, a 20-year-old woman, disclosed verbal abuse concerning her weight and intellectual abilities by family members and peers. This abuse occurred on and off during her preadolescence and adolescence. Anya had wanted to become a teacher since she was 4 years old. Unlike Isabella, who spoke passionately about effecting personal and social change, Anya talked about wanting to make people aware without necessarily affecting their lives in a serious way. She was adamant about not working with preschool or elementary school age children, but preferred to focus on becoming a high school teacher. Focusing on having a one-way impact on adolescents, she used images of the teacher-as-convincer. "I'm interested in opening up people's perspectives. Making people aware of 'invisible minorities' [e.g., gays and lesbians], getting them to think about all these hidden messages. ... . That's important. You can't change things. . . Y You can only make people aware."

The other participant who fit the profile of a negative case was a 26year-old woman of color majoring in an environmental science. Jenny, the product of an alcoholic system in which emotional abuse was present, related that, for her, the career came first and wanting to make a difference came second.

I think my interest in the environment came from my spending so much time in the ravine and the woods near my home when I was a kid ... especially when my parents' drinking was really out of control. I liked being alone, out of the turmoil. I still like it.

Though she would like to effect change, she was not looking for "monumental change." Jenny stated:

I don't have the strength . . . the stamina . . . to do that. But I would like my work with the environment to serve as a point [of change] for others. My dream is to advise an environmental group in a major city that would take my data and work for environmental change.

A limiting component to the influence of childhood abuse seemed to be the type of abuse: women who had experienced a component of physical or sexual abuse elaborated the categories of safety or career-as-mission; those who used metaphors of distance had experienced emotional abuse. 


\section{BOUNDARIES OF THE INQUIRY}

Since this inquiry occurred in a particular time and place, under particular circumstances with unique individuals (Wolcott, 1990), the emergent themes and dynamics should be viewed as atypical; however, limited transferability may be warranted. At the very least, these cases expanded and enriched the repertoire of social constructions about childhood abuse shaping university course selection and subsequent career paths for some women. Certain trends, especially regarding the selection of courses or perceived career options, could be formulated into working hypotheses and carried over to new situations (Donmoyer, 1990), assessing a degree of fit with a changing context with different constituents.

As well, given the sample size and the nature of the sampling procedure, it is important to note that a causal connection cannot be drawn. However, this project has revealed some important themes that were salient for the women who were interviewed. Future research is needed to more thoroughly investigate abuse survivors of both genders in traditional and more nontraditional fields (e.g., engineering and the pure sciences) and with those whose abusers were female.

\section{DISCUSSION}

The results of this study have far-reaching implications counseling women for career choice in higher education. A portion of the women interviewed felt anxiety and fear when making life choices. These states of emotional arousal appeared to decrease career-related self-efficacy (Hackett $\&$ Betz, 1981), and these women used safety rather than interest or ability to determine their career path. Therefore, childhood physical and sexual abuse functioned as a limit to circumscribe perceived career options (Gottfredson, 1981) to a reduced range of appropriate alternatives, that is, fields dominated by women. Sexual abuse, in particular, may be a dimension that supports occupational sex segregation. Fear of revictimization seemed to interact with fear of success and reduced risk-taking behavior, substantiated barriers for women's career aspirations (Farmer, 1976).

The impact of devastating abuse on the self-concept of these survivors also tended to restrict choices (Betz \& Fitzgerald, 1987). All of the women in this theme category spoke about personal qualities (lack of education or intelligence and an inability to concentrate on or learn concepts) that limited the range of fields that were open to them. These results may serve 
to partially explain the pattern of underutilization of abilities demonstrated by women in career achievement (Betz, 1994). In addition, vocations dominated by men were perceived as filled with the potential for sexual harassment, which further served to circumscribe these women's career alternatives (Farmer, 1976).

For another group of women, childhood physical and sexual abuse also had an impact on their career choice, though toward a different end. These women were trying to eliminate the conditions that supported these kinds of abuse. Through their career choice, they would become an instrument for social change. This sense of future purpose was a crucial element to their healing. However, their career options were still circumscribed, in that they were drawn to the "helping professions," many of which are dominated by women and are within the stereotypical female professional career sphere (Betz, 1994). Though based on proactive choice, the end result was much the same: the continued occupational segregation and limitation of career alternatives for women, and the reinforcement of occupational stereotypes.

Therefore, child physical and sexual abuse may function as a determining influence for established variables that have been linked to career choice for women. These experiences may function on many levels, either as a "debilitating" or "precipitating" factor (Sobol, 1963 as cited in Betz \& Fitzgerald, 1987), dependent upon the woman survivor's cognitive construction of the events and the meaning made of the experiences. These patterns of abuse may play a profound impact on tailoring a woman's sex role attitude, fear of success, academic and performance self-esteem, and risk-taking behavior, or, as an environmental barrier by heightening sensitivity and vulnerability to the potential of sexual harassment (Betz, 1994; Farmer, 1976). For some women a career within a traditional sphere that addressed the physical and psychological "survival" needs of safety (Astin, 1984) was a preferable option to one that embodied potential danger in a nontraditional one.

Being in university departments populated by women also restricted the participants' exposure to female role models in nontraditional fields, thereby cultivating lower career self-efficacy in nontraditional occupations (Betz, 1994; Hackett \& Betz, 1981). Sensitivity to potential power dynamics with male professors prevented some women from even taking courses with them, let alone developing mentoring relationships. This blueprint for relationships with female and male faculty might serve to seriously restrict the range of career options and success within male-dominated fields. 
The key difference among the women who expressed the major themes of safety and transformation is the cognitive construction of past experiences coupled with the kind and strength of the emotion and arousal to the career "barrier" of past child abuse experiences. This link between thought/ emotion interaction and barrier perception has been seen as a fundamental key to coping with barriers (London, 1998). For women still caught by the fear and anxiety, who re-experienced these emotional states, safety was primary. For those women who transformed their fear and anxiety into righteous anger and action toward "a wrong committed," career served as a constructive vent to these feelings.

Given the established link between "acceptable" career aspirations for women and a woman's self-concept along with perceptions of occupations (Gottfredson, 1981), it is important to consider the long-term effects of child abuse as part of the career assessment process, and in the context of university academic advising. Chronister, Wettersten, and Brown (2004) have called on researchers to include the vocational experiences and needs of battered women so that vocational research can contribute to the liberation of battered women. This inclusion must also extend to childhood survivors of abuse. Considering the number of women who have experienced childhood violence (Herman, 1997; Meichenbaum, 1994; Root, 1996; Terr, 1991), abuse can be considered a critical incident, which may affect the career development of a survivor (Hackett \& Lonborg, 1994). Childhood violence is a gender issue, which has long been neglected in the assessment process (Brown, 1990; Hackett \& Lonborg, 1994). As well, abuse may influence a woman's gender-role socialization, a key element in career assessment (Brooks \& Forrest, 1994).

\section{IMPLICATIONS FOR PRACTICE}

The main function of this project was to offer insight and illuminate meaning. Streaming into limited career paths is now shown to be another possible long-range effect of child abuse. We offer some suggestions to practitioners about the implications of these themes in a higher education setting.

\section{In a Higher Education Institutional Context}

Everyone within a higher educational setting needs to become familiar with the long-term signs of early abuse. Understanding some of these 
behavioral patterns as attributable to early abuse, rather than irrational anxiety or sex role stereotypes, creates climates, which help women realize their full potential. Horsman (2000) emphasized that the only way to adequately transform educational programs is to shift consciousness of the connections between violence and learning, and consequently career choice, to the forefront; it is the only way that changes in educational programs can begin to be pictured. "Shifting conceptions will require constant vigilance because it is all too easy to slide back into taken-forgranted conceptual frameworks [of violence]" (p. 329). More resources, therefore, must be allocated to support women's career processes. As with any change, institutional change can only occur if all levels are involved, such as program administrators, program advisors, instructors, support staff, and other students. At the same time, additional resources need to be allocated. Tutors, vocational skills and career options workshops for women, career fairs exploring traditional and nontraditional careers for women with living representatives of those careers, and mentoring support within disciplines would go a long way to sustain the widening of career alternatives for women survivors of childhood abuse.

Horsman (2000) also emphasized a holistic approach to the educational experience, where the focus is on exploring, taking charge, and enabling the whole person to support life choices and learning. This approach would empower women to make career choices based on possibilities, desires, and dreams, rather than on safety, mission, or distance. There must be a priority in creating safe environments, real and perceived, in all departments and classrooms within higher education. Safety is created by the policies that we implement, by the language that we use and the actions we take, and by being continually aware of the impact of trauma on career choice.

\section{In Student Advising and Career Counseling}

Vocational counseling cannot be divorced from psychological counseling when working with women who have experienced abuse. Part of the intake interview should address a client's experience of violence, and the consequences of silence and shame associated with it. Counselors working in university settings need to be aware of the pervasiveness of students who have experienced violence and the way that it impacts educational choices. The damage from abuse needs to be considered when assessing course selection, major declaration, and career counseling; the psychic damage from abuse needs to be considered when forming 
relationships with students and in discussing how women survivors form learning relationships with peers. As Horsman (2000) stated, "It is not just the mind that goes to school-it is the whole person" (p. 334).

As some participants in this inquiry reported, the fear of revictimization causes high anxiety, which interacts with fear of success, creating substantiated barriers for women's career aspirations. It is within this context that counselors need to listen and provide a therapeutic venue that addresses not only the psychological needs of the client, but also her vocational future.

\section{REFERENCES}

Angrasino, M., \& Mays de Perez, K. (2000). Rethinking observation: From method to context. In N. Denzin \& Y. Lincoln (Eds.), Handbook of qualitative research (2nd ed.) (pp. 673-702). Thousand Oaks, CA: Sage Publications.

Astin, H. (1984). The meaning of work in women'slives: Asociopsychological model of career choice and work behavior. The Counseling Psychologist, 12, 117-126.

Belenky, M., Clinchy, B., Goldberger, N., \& Tarule, J. (1986). Women's ways of knowing: The development of self, voice, and mind. New York: Basic.

Benson, D., \& Thomson, G. (1982). Sexual harassment on a university campus: The confluence of authority relations, sexual interest and gender stratification. Social Problems, 29, 236-251.

Betz, N. (1994). Basic issues and concepts in career counseling for women. In W. B. Walsh \& S. Osipow (Eds.), Career counseling for women (pp. 1-41). Hillsdale, NJ: Lawrence Erlbaum.

Betz, N., \& Fitzgerald, L. (1987). The career psychology of women. New York: Academic Press.

Betz, N., \& Hackett, G. (1986). Applications of self-efficacy theory to understanding career choice behavior. Journal of Social and Clinical Psychology, 4, 279-289.

Bogdan, R., \& Biklen, S. (1998). Qualitative research in education: An introduction to theory and methods (3rd ed.). Boston: Allyn \& Bacon.

Brooks, L., \& Forrest, L. (1994). Feminism and career counseling. In W. B. Walsh \& S. Osipow (Eds.), Career counseling for women (pp. 87-134). Hillsdale, NJ: Lawrence Erlbaum. 
Brown, L. (1990). Taking gender into account in the clinical assessment interview. Professional Psychology, 21, 12-17.

Browne, A., \& Finkelhor, D. (1986). Impact of child sexual abuse: A review of the literature. Psychological Bulletin, 99(1), 66-77.

Chronister, K., \& McWhirter, E. (2004). Ethnic differences in career supports and barriers for battered women: A pilot study. Journal of Career Assessment, 12, 169-187.

Chronister, K., Wettersten, K., \& Brown, C. (2004). Vocational research for the liberation of battered women. The Counseling Psychologist, 32, 900-922.

Dey, I. (1999). Grounding grounded theory: Guidelines for qualitative inquiry. San Diego, CA: Academic.

Dickinson, J. (November, 1991). Toward a cognitive developmental understanding of child sexual abuse: Clinical interviews with adult women sexually abused in childhood. Dissertation Abstracts International, 52(5-A), 1687.

Donmoyer, R. (1990). Generalizability and the single-case study. In E. Eisner \& A. Peshkin (Eds.), Qualitative inquiry in education: The continuing debate (pp. 175-200). New York: Teachers College Press.

Farmer, H. (1976). What inhibits achievement and career motivation in women? The Counseling Psychologist, 6, 12-14.

Fassinger, R. (1985). A causal model of career choice in college women. Journal of Vocational Behavior, 27, 160-175.

Fassinger, R. (1996). Notes from the margins: Integrating lesbian experience into the vocational psychology of women. Journal of Vocational Behavior, $48,160-175$.

Finkelhor, D., \& Browne, A. (1985). The traumatic impact of child sexual abuse: A conceptualization. American Journal of Orthopsychiatry, 55(4), 530-541.

Fiorentine, R. (1988). Sex differences in success expectancies and causal attributions: Is this why fewer women become physicians? Social Psychology Quarterly, 51, 236-249.

Fonow, M., \& Cook, J. (1991). Back to the future: A look at the second wave of feminist epistemology and methodology. In M. Fonow \& J. Cook (Eds.), Beyond methodology: Feminist scholarship as lived research (pp. 1-15). Indianapolis: Indiana University Press.

Glazer, B., \& Strauss, A. (1967). The discovery of grounded theory: Strategies for qualitative research. Chicago: Aldine. 
Goldwasser, S. (1992). Relationships, mothers and daughters, fathers and daughters: A key to the development of competence? (ERIC Document Reproduction Service No. ED361 618)

Gottfredson, G. (1981). Circumscription and compromise: A development theory of occupational aspirations. Journal of Counseling Psychology, 28, 545-579.

Hackett, G., \& Betz, N. (1981). A self-efficacy approach to the career development of women. Journal of Vocational Behavior, 18, 326-339.

Hackett, G., \& Byars, A. (1996). Social cognitive theory and the career development of African American women. Career Development Quarterly, 44, 322-340.

Hackett, G., \& Lonborg, S. (1994). Career assessment and counseling for women. In W. B. Walsh \& S. Osipow (Eds.), Career counseling for women (pp. 43-85). Hillsdale, NJ: Lawrence Erlbaum.

Herman, J. (1997). Trauma and recovery: The aftermath of violence from domestic abuse to political terror. New York: Basic Books.

Horsman, J. (2000). Too scared to learn: Women, violence, and education. Mahwah, NJ: Lawrence Erlbaum.

Intergovernmental Committee on Family Violence (1991). Woman abuse protocols. St. John, NB: Government of New Brunswick.

Larkin, J. (1994). Sexual harassment: High school girls speak out. Toronto: Second Story Press.

Lincoln, Y., \& Guba, E. (1985). Naturalistic inquiry. Beverly Hills, CA: Sage.

London, M. (1998). Career barriers: How people experience, overcome, and avoid failure. Mahwah, NJ: Lawrence Erlbaum.

Love, R. (1986). "I'm really different": Difficulties in balancing a business career with a liberal arts self-concept. Journal of American College Health, 34, 210-215.

Luzzo, D., Funk, D., \& Strang, J. (1996). Attributional retraining increases career decision-making self-efficacy. Career Development Quarterly, 44, 378-386.

Mansfield, P., Koch, P., Henderson, J., Vicary, J., Cohan, M., \& Young, E. (1991). The job climate for women in traditionally male blue-collar occupations. Sex Roles, 25, 63-80.

Maxwell, J. (1996). Qualitative research: An interactive approach. Thousand Oaks, CA: Sage Publications. 
Meichenbaum, D. (1994). A clinical handbook / practical therapist manual for assessing and treating adults with post-traumatic stress disorder (PTSD). Waterloo, ONT: Institute Press.

Meis, M. (1991). Women's research or feminist research?: The debate surrounding feminist science and methodology. In M. Fonow \& J. Cook (Eds.), Beyond methodology: Feminist scholarship as lived research (pp. 60-84). Indianapolis: Indiana University Press.

Merriam, S. (1998). Qualitative research and case study applications in education. San Francisco: Jossey-Bass.

Miles, M., \& Huberman, A. (1994). An expanded sourcebook: Qualitative data analysis (2nd ed.). Thousand Oaks, CA: Sage Publications.

Moe, A., \& Bell, M. (2004). The effects of battering and violence on women's work and employability. Violence Against Women, 10, 29-55.

Newberger, C., \& DeVos, E. (1988). Abuse and victimization: A life span developmental approach. American Journal of Orthopsychiatry, 58, 505-511.

Oakley, A. (1981). Interviewing women: A contradiction in terms. In H. Roberts (Ed.), Doing feminist research (pp. 30-61). Boston: Routledge $\&$ Kegan Paul.

Ramazanoglu, C., \& Holland, J. (2002). Feminist methodology: Challenges and choices. Thousand Oaks, CA: Sage Publications.

Reilly, R. C., \& D'Amico, M. (2002). The impact of sexual and physical violence on women's' learning processes: Implications for child and youth care workers in educational settings. Journal of Child and Youth Care, 17, 166-186.

Reinharz, S. (1992). Feminist methods in social research. New York: Oxford University Press.

Reis, S. (1995). Talent ignored, talent diverted: The cultural context underlying giftedness in females. Journal of Secondary Gifted Education, 6, 162-170.

Root, M. (1996). Women of color and traumatic stress in "domestic captivity": Gender and race as disempowering statuses. In A. Marsella, M. Friedman, E. Gerrity, \& R. Scurfield (Eds.), Ethnocultural aspects of post traumatic stress disorder: Issues, research, and clinical applications (pp. 363-388). Washington, D.C.: American Psychological Association.

Rotberg, H., Brown, D., \& Ware, W. (1987). Career self-efficacy expectations and perceived range of career options in community college students. Journal of Counseling Psychology, 34, 164-170. 
Roundtree, J., \& Frusher, S. (1991). Fear of career development success among women: Implications for community college educators. Community-Junior College Quarterly of Research \& Practice, 15, 203209.

Seale, C. (1999). The quality of qualitative research. Thousand Oaks, CA: Sage Publications.

Seidman, I. (2006). Interviewing as qualitative research: A guide for researchers in education and the social sciences (3rd ed.). New York: Teachers College Press.

Stanley, L., \& Wise, S. (1993). Breaking out again: Feminist ontology and epistemology. New York: Routledge.

Strauss, A., \& Corbin, J. (1998). Basics of qualitative research: Techniques and procedures for developing grounded theory ( $2 \mathrm{nd}$ ed.). Thousand Oaks, CA: Sage Publications.

Swanberg, J., \& Logan, T. (2005). Domestic violence and employment: A qualitative study. Journal of Occupational Health Psychology, 10, 3-17.

Swerdlow, M. (1989). Men's accommodations to women entering a nontraditional occupation: A case of rapid transit operatives. Gender \& Society, 3, 373-387.

Tangri, S., Burt, M., \& Johnson, L. (1982). Sexual harassment at work: Three exploratory models. Journal of Social Issues, 38(4), 33-54.

Terr, L. (1991). Childhood traumas: An outline and overview. American Journal of Psychiatry, 148, 10-20.

Vygotsky, L. (1987). Thought and language. (A. Kozulin, Ed.). Cambridge, MA: MIT Press.

Wettersten, K., Rudolph, S., Faul, K., Gallagher, K., Trangsrud, H., Adams, K., Graham, S., \& Terrance, C. (2004). Freedom through self-sufficiency: A qualitative examination of the impact of domestic violence on the working lives of women in shelter. Journal of Counseling Psychology, 51, 447462.

Whiston, S. (1996). The relationship among family interaction patterns and career indecision and career decision-making self-efficacy. Journal of Career Development, 23, 137-149.

Wolcott, H. (1990). Writing up qualitative research. Newbury Park, CA: Sage.

Working Women's Institute. (1980). Sexual harassment on the job: Questions and answers. New York: Author.

Yewchuk, C. (1994). Gender issues in education. (ERIC Document Reproduction Service No. ED371 553) 